\title{
The Presence of Turkish Accent in the Iranian Turkish Speaking People's Farsi Contrasted with its Absence in Their Speaking English: Minimal Overwhelms Maximal Bilingualism
}

\author{
Ataollah Maleki \\ English Language Department, Faculty of Medicine, Zanjan Medical Sciences University, Zanjan, Iran \\ Email: atamaleki@hotmail.com
}

\begin{abstract}
The terms minimal and maximal bilingualism are respectively defined as incipient and native like ability to use a second language. The presence of Turkish accent in the Iranian Turkish speaking people's Farsi, with its absence in their speaking English contradicts the contrast between minimal and maximal dichotomy in bilingualism. These people do not speak Farsi, which is deeply rooted in their culture and way of life, as fluently as English to which they are lightly exposed. A five point Likert scale analysis of ten attitude statements about Farsi and English checked off by 49 out of 490 Iranian Turkish speaking students showed that attitude was the main cause of the problem. Thus, positive or negative attitude toward a second language can facilitate or hinder learning it.
\end{abstract}

Index Terms—bilingualism, maximal and minimal bilingualism, Turkish, Farsi, attitude, Likert scale

\section{INTRODUCTION}

The term bilingualism has many different meanings. On individual level it refers to consecutive or simultaneous learning/acquisition of a second language and involves issues of language competence, performance, ability, proficiency, and achievement. On a societal level it refers to complex phenomena of minority and migrants. The latter concerns with concepts such as diglossia and domain that are helpful in understanding the different ways in which linguistic resources are organized in multilingual communities, including phenomena such as borrowing, interference, transfer, and code switching.

Another important distinction is between ability (competence) and use, sometimes referred to as the difference between degree and function. Bilingualism and multilingualism often involve different degrees of competence in the languages involved. A person may control one language better than another, or a person might have mastered different languages better for different purposes, using one language for speaking, for example, and another for writing. Skutnab Kangas (1984) distinguishes four categories within bilingual ability: maximal (native like) and minimal (incipient) bilingualism, balanced bilingualism (dual language proficiency), semilingualism, and double semilingualism.

Separate from bilingual ability is a person's use of their two languages, referred to as functional bilingualism (Baker, \& Jones, 1998) that concerns the contexts (domains) and targets (people), that is, when, where, and with whom people use their two languages.

Iran is a multilingual country. There are three major languages spoken by the people on the land. Farsi (Persian) is the most widespread and the national language. Turkish is the second widespread language with Kurdish the third. Farsi as a second language is the language of education for all minorities from primary school to higher education. It is the official language of radio, TV, and the press. There are, however, few local radio and TV stations broadcasting in Turkish or Kurdish. There are also few local newspapers and magazines, because only a limited number of Turk minorities can read Turkish script. Therefore, these ethnic groups should rely on Farsi for their communication and correspondence purposes. A majority of the members of these minority groups learn Farsi when they are young children, and use it throughout their lives. The situation may be described as true or maximal bilingualism.

English in Iran, on the other hand, is taught as a foreign language at second year of junior secondary school and continues throughout the university years. Exposure to English is limited, and there is little opportunity to use it. In general, the teaching of English does not enjoy high quality with systematic planning and proceeding. This is especially true for the minorities. Hence, knowledge of English is generally poor among ethnic groups. Here, the situation of English in relation to minority languages such as Turkish and Kurdish can be described as minimal or incipient bilingualism. As it stands, maximal bilingualism is normally more forceful than minimal (incipient) bilingualism. However, in the case of Farsi and English as additive languages there is an opposite situation. Turkish learners of English speak English with little or no trace of Turkish accent. Conversely, in their speaking Farsi, Turkish accent is obvious, and one can immediately guess their nationality. This is an intriguing problem which needs an investigation. It 
overwhelms the set rules of bilingualism psychology and raises the question whether the problem arises from psychological factors.

\section{A. Review of Literature}

People use the term "bilingualism" in different ways. For some, it means an equal ability to communicate in two languages. For others, it simply means the ability to communicate in two languages, but with greater skills in one language. In fact, it is more common for bilingual people, even those who have been bilingual since birth, to be somewhat dominant in one language. The term bilingualism has opened up new discursive space of linguistic in betweeness, and, hence, has furnished several neologisms: bilinguality, diglossia, regionalism, semilingualism, double semilingualism, balanced bilingualism (dual language proficiency), maximal bilingualism, minimal bilingualism, etc.

Hamers and Blanc (2000) have defined bilinguality as the psychological state of an individual who has access to more than one linguistic code as means of social communication. The degree of access will vary along a number of dimensions which are psychological, cognitive, psycholinguistic, sociocultural and linguistic. There has been a tradition of research into bilingualism since the mid 20th century. However, whether this research belongs to the fields of neuropsychology, developmental psychology, experimental psychology, cognitive psychology, psycholinguistics, social psychology, sociolinguistics, sociology, anthropology, ethnology, political and economic sciences, education or linguistics, the underlying issue remains undoubtly the same: the use of at least two languages.

In considering bilingualism as a privileged form of language contact, a great number of linguists have argued over exact meaning of this inferred usage of two languages. Bloomfield (1933) believes that bilingualism is the native control of two languages. Recently, however, second language acquisition studies have contested this as all encompassing view of bilingualism. For example, Selinker (1971) argues that only five percent of second language speakers have absolute success in their second tongue. Others such as Bley Vroman (1989), Birdsong (1992), and Cook (1993) have rejected monolingual competence as a frame of reference for bilingualism. Still others contend to subscribe to some extent to the two extremes. Toribio (2001), for instance, thinks that bilingualism is, in fact, a native like ability in two languages based on the standard of an idealized bilingual native speaker's competence.

Another controversial question is the issue of control and proficiency. Proficiency can be maximal (Haugen, 1953) or minimal (MacNamara, 1967). Haugen (1953) thinks that bilingualism is the point where a speaker can produce complete meaningful utterances in the other language. MacNamara (1967), on the other hand, argues that a bilingual is anyone who possesses a minimal competence in only one of the four language skills: listening comprehension, speaking, reading and writing. It has also been claimed that the use of two languages is informed by behaviour and, as such, a question of performance. Weinreich (1966) discussed bilingualism in terms of alteration. According to him, the practice of alternatively using two languages will be bilingualism. In turn, Mackey (1976) spoke of the separation of two languages. In speaking to identify bilingualism with code switching, these researchers inspired others to study bilingualism in relation to interference, code mixing, borrowing and interlanguage. Beyond this, bilingualism was linked with translation ability and metalinguistic awareness. Weinreich (1966) writes that when speaking to a monolingual, the bilingual is subject to interlocutory constraint which requires that he or she limit interferences, but when speaking to another bilingual, there is hardly any limit to interferences; forms can be transferred freely from one language to the other and often used in an unadapted way. Hasselmo (1970) notes that there are two extremes in the behaviour of certain bilinguals: one involving minimal and the other maximal code switching. Baetens Beardsmore (1982) believes that bilinguals in communication with other bilinguals may feel free to use both of their language repertoires. However, the same bilingual speakers in conversation with monoglots may not feel the same liberty and may well attempt to maximise alignment on monoglot norms by consciously reducing any formal interference features to a minimum.

Another related topic is the question of attitude. As a theoretical construct, attitudes are said to contain various dimensions. The dimensions of attitude are grounded in the area of social psychology, which have been identified by researchers as cognition, affect, and behaviour (Rosenberg and Hovland, 1960; Shaw and Wright, 1967). Rosenberg and Hovland (1960) developed a model of attitude. According to these researchers, the cognitive element of attitude concerns perceptions, concepts, and beliefs regarding the attitude object. For example, a stated belief about the importance of a language and its value may contribute to a favourable attitude. The affective component of attitude includes feelings toward the object of the attitude, such as the language itself. Affect may include love or dislike of the language or anxiety over learning the language. Cognition and affect are not necessarily in harmony with one another. That is, a person may express a positive attitude toward a bilingual situation, but may covertly have negative feelings toward it. The third factor is the action or behaviour component. This aspect of attitude concerns a predisposition or intention to behave in a certain way. For example, a person with a positive attitude toward the English language may send their child to an English teaching institute or may attend English classes themselves. The researchers suggest that evaluation of the affective component has been central to the understanding of attitude.

In Rosenberg and Hovland's model, the three dimensions or intervening variables of attitude are displayed along the same plane. Shaw (1967), however, argues that the nature of the three dimensions of attitude is not arranged as Rosenberg and Hovland suggest. Rather, Shaw defines attitude as, "A set of affective reactions toward the attitude object, derived from the concepts or beliefs that the individual has concerning the object, and predisposing the individual to behave in a certain manner toward the attitude object" (p. 13). 
Other researchers such as Gardner (1985) and Baker (1992) have teased out the various dimensions of attitude. Gardner's 1985 work in the area of social psychology specifically explores attitude toward second language acquisition. He suggests that measuring attitude is more straightforward for attitude objects or referents than it is for abstract ideas. According to Gardner, attitude is only one component of motivation, where motivation is also comprised of effort and desire to learn.

Similarly, Baker (1992) differentiates the various facets of attitudes that are related to language. For example, Baker suggests that attitudes can be measured as attitudes toward a particular language itself, toward language groups, toward language use, features, cultural associations, or learning; and toward bilingual education, either as process or product.

Language attitude can be measured using a variety of techniques, either quantitative or qualitative in nature (Baker, 1992; Fowler, 1993; Henerson et al., 1987). These techniques may include surveys, document analyses, interviews, case studies, and autobiographies. Among the most common measures of attitude are surveys. Surveys can employ a variety of measures including Likert, Guttman, or Semantic Differential Technique.

\section{B. The Research Question}

Does minimal bilingualism overwhelm maximal bilingualism?

\section{The Hypothesis}

Minimal bilingualism overwhelms maximal bilingualism.

\section{MEthodology}

\section{A. Participants}

49 Iranian Turkish speaking students took part in the experiment. They all had taken general English as part of the courses they were majoring in. They were randomly selected out of 490 male and female Turkish speaking students studying in Persian and Turkish based universities. Their age ranged between 18-25 years. Their first language was Turkish and were exposed to Farsi from childhood.

\section{B. Materials and Procedures}

At first, the subjects were asked to learn by heart and to orally reproduce English stories which were selected from Hill's (1979) "Elementary Stories for Reproduction: Series 2." Later, they were asked to orally reproduce Persian stories found in old and modern Persian literature. All were recorded and compared. This was done to make sure that the stated problem was consistent and widely distributed among the subjects.

Next, two questionnaires based on a five point Likert Scale were given to the subjects to complete. They were asked to indicate their degree of agreement with the statements in the questionnaires regarding the status, general acceptability, and attractiveness of English and Farsi (Appendixes A \& B). Each degree of agreement was given a numerical value from one to five. Then the total value of all responses was converted to percentages. The percentages of response to each statement about Farsi and English were then compared to find the differences. Finally, the Chi square test was used to see if the differences were not due to chance occurrence.

There was also a group statistical analysis. The mean value of all responses to each statement was computed, and all the means were compared for responses to each statement about Farsi and English. A 2 tailed t test for equality of means was applied to see if the mean differences were not due to chance.

Cronbach Alpha was used to assess the reliability of the statements. Cronbach Alpha value (0.8944) proved the consistency and reliability of the statements (Table 1).

TABLE 1

CRONBACH AlPHa ANALYSIS OF THE STATEMENTS

\begin{tabular}{|c|c|c|c|c|}
\hline \multicolumn{5}{|c|}{ Item-total statistics } \\
\hline & Scale & Scale & Corrected & \\
\hline & Mean & Variance & Item & Alpha \\
\hline & if Item & if Item & Total & if Item \\
\hline & Deleted & Deleted & Correlation & Deleted \\
\hline S1 & 32.4839 & 72.8581 & .5937 & .8868 \\
\hline S2 & 32.2581 & 73.9312 & .5122 & .8922 \\
\hline S3 & 31.5484 & 73.1226 & .6862 & .8820 \\
\hline S4 & 32.0000 & 71.3333 & .6239 & .8849 \\
\hline S5 & 31.8387 & 67.8065 & .8142 & .8717 \\
\hline S6 & 32.1935 & 69.6280 & .7113 & .8789 \\
\hline S7 & 32.0968 & 84.9570 & .0403 & .9159 \\
\hline S8 & 31.9677 & 70.0323 & .7891 & .8748 \\
\hline S9 & 32.6774 & 65.0258 & .8404 & .8685 \\
\hline S10 & 32.6129 & 63.7118 & .7674 & .8747 \\
\hline \multicolumn{5}{|c|}{$\begin{array}{l}\text { Reliability Coefficients } \\
\mathrm{N} \text { of Cases }=31.0\end{array}$} \\
\hline \multicolumn{3}{|c|}{ Alpha $=.8944$} & \multicolumn{2}{|c|}{$\mathrm{N}$ of Item $=10$} \\
\hline
\end{tabular}




\section{RESULTS}

Data analysis of the responses to the first statement, that is, "I'd like to speak Farsi/English all the time" showed that $38.8 \%$ of the subjects strongly agreed to speak English all the time; whereas only $6.1 \%$ of them strongly agreed to speak Farsi all the time (Table 2).

TABLE 2

ANALYSIS OF STATEMENT 1

\begin{tabular}{|l|l|l|l|l|}
\hline \multicolumn{2}{|c|}{} & Group & \multirow{2}{*}{ Total } \\
\cline { 3 - 4 } S1 & Strongly disagree & Farsi & English & \\
\cline { 2 - 5 } & Disagree & 10 & 2 & 12 \\
& & $20.4 \%$ & $4.1 \%$ & $12.2 \%$ \\
\cline { 2 - 5 } & Neither agree nor disagree & 18 & 6 & 24 \\
& & $36.7 \%$ & $12.2 \%$ & $24.5 \%$ \\
\cline { 2 - 5 } & Agree & $28.6 \%$ & 4 & 18 \\
& & 4 & $8.2 \%$ & $18.4 \%$ \\
\cline { 2 - 5 } & Strongly agree & $8.2 \%$ & 18 & 22 \\
& & 3 & $36.7 \%$ & $22.4 \%$ \\
\hline \multirow{2}{*}{ Total } & $6.1 \%$ & 19 & 22 \\
& & 49 & $38.8 \%$ & $22.4 \%$ \\
\hline
\end{tabular}

\begin{tabular}{|l|l|l|l|}
\hline Chi Square Tests & Value & df & Asymp.Sig. (2 sided) \\
\hline Pearson Chi Square & 37.434 & 4 & .000 \\
Likelihood Ratio & 40.594 & 4 & .000 \\
Linear by Linear & 30.332 & 1 & .000 \\
Association & & & \\
N of Valid Cases & 98 & & \\
\hline
\end{tabular}

The difference between the two, which was confirmed by Chi Square test, was significant $(\mathrm{P}=0.0005)$. The difference between the responses to the second statement, that is, "Learning Farsi/English is a privilege" was also significant $(\mathrm{P}=0.016)$. Only $12.5 \%$ strongly agreed with English. The Chi Square test confirmed the result (Table 3).

TABLE 3

ANALYSIS OF STATEMENT 2

\begin{tabular}{|c|c|c|c|c|}
\hline & & \multicolumn{2}{|l|}{ Group } & \multirow[t]{2}{*}{ Total } \\
\hline & & Farsi & English & \\
\hline \multirow[t]{5}{*}{$\mathrm{S} 2$} & Strongly disagree & $\begin{array}{l}8 \\
16.7 \%\end{array}$ & $\begin{array}{l}5 \\
10.4 \%\end{array}$ & $\begin{array}{l}13 \\
13.5 \%\end{array}$ \\
\hline & Disagree & $\begin{array}{l}7 \\
14.6 \% \\
\end{array}$ & $\begin{array}{l}3 \\
6.3 \% \\
\end{array}$ & $\begin{array}{l}10 \\
10.4 \% \\
\end{array}$ \\
\hline & Neither agree nor disagree & $\begin{array}{l}10 \\
20.8 \% \\
\end{array}$ & $\begin{array}{l}8 \\
16.7 \% \\
\end{array}$ & $\begin{array}{l}18 \\
18.8 \% \\
\end{array}$ \\
\hline & Agree & $\begin{array}{l}17 \\
35.4 \%\end{array}$ & $\begin{array}{l}11 \\
22.9 \%\end{array}$ & $\begin{array}{l}28 \\
29.2 \%\end{array}$ \\
\hline & Strongly agree & $\begin{array}{l}6 \\
12.5 \% \\
\end{array}$ & $\begin{array}{l}21 \\
43.8 \% \\
\end{array}$ & $\begin{array}{l}27 \\
28.1 \% \\
\end{array}$ \\
\hline \multicolumn{2}{|c|}{ Total } & $\begin{array}{l}48 \\
100.0 \%\end{array}$ & $\begin{array}{l}48 \\
100.0 \%\end{array}$ & $\begin{array}{l}96 \\
100.0 \%\end{array}$ \\
\hline
\end{tabular}

\begin{tabular}{|l|l|l|l|}
\hline Chi Square Tests & Value & df & Asymp.Sig. (2 sided) \\
\hline Pearson Chi Square & 12.134 & 4 & .016 \\
Likelihood Ratio & 12.688 & 4 & .013 \\
Linear by Linear & 6.501 & 1 & .011 \\
Association & & & \\
N of Valid Cases & 96 & & \\
\hline
\end{tabular}

Responses to the third statement indicated that for the subjects English was a more attractive language than Farsi $(61.2 \%$ to $34.7 \%$ strongly agreed $)(\mathrm{P}=0.042)$. Table 4 presents the data. 
TABLE 4

ANALYSIS OF STATEMENT 3

\begin{tabular}{|l|l|l|l|l|}
\hline \multicolumn{2}{|c|}{} & \multicolumn{2}{|l|}{ Group } & \multirow{2}{*}{ Total } \\
\cline { 3 - 4 } \multicolumn{2}{|c|}{} & Farsi & English & \\
\hline \multirow{4}{*}{ S3 } & Strongly disagree & 6 & 1 & 7 \\
& & $12.2 \%$ & $2.0 \%$ & $7.1 \%$ \\
\cline { 2 - 4 } & Disagree & 2 & 1 & 3 \\
& & $4.1 \%$ & $2.0 \%$ & $3.1 \%$ \\
\cline { 2 - 4 } & Neither agree nor & 8 & 3 & 11 \\
& disagree & $16.3 \%$ & $6.1 \%$ & $11.2 \%$ \\
\cline { 2 - 4 } & Agree & 16 & 14 & 30 \\
& & $32.7 \%$ & $28.6 \%$ & $30.6 \%$ \\
\cline { 2 - 5 } & Strongly agree & 17 & 30 & 47 \\
& Total & $34.7 \%$ & $61.2 \%$ & $48.0 \%$ \\
\hline
\end{tabular}

\begin{tabular}{|l|l|l|l|}
\hline Chi Squared Tests & Value & df & Asymp.Sig. (2 sided) \\
\hline Pearson Chi Square & 9.907 & 4 & .042 \\
Likelihood Ratio & 10.437 & 4 & .034 \\
Linear by Linear & 9.174 & 1 & .002 \\
Association & 98 & & \\
N of Valid Cases & 98 & & \\
\hline
\end{tabular}

There was a strong agreement with statement No.4. $56.3 \%$ compared with $12.2 \%$ of the subjects strongly agreed that knowing English helps them get a better job (0.0005) (Table 5).

TABLE 5

ANALYSIS OF STATEMENT 4

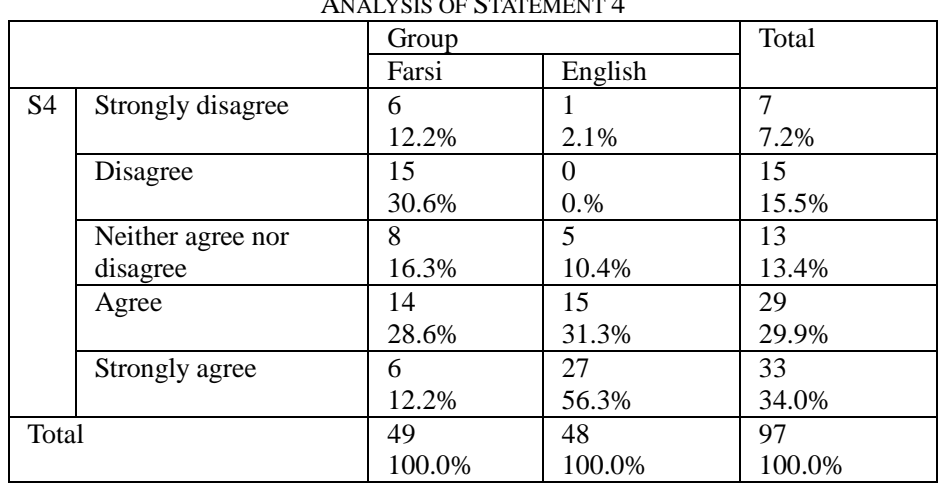

\begin{tabular}{|l|l|l|l|}
\hline Chi Squared Tests & Value & df & Asymp.Sig. (2 sided) \\
\hline Pearson Chi Square & 32.655 & 4 & .000 \\
Likelihood Ratio & 39.934 & 4 & .000 \\
Linear by Linear & 29.347 & 1 & .000 \\
Association & & & \\
N of Valid Cases & 97 & & \\
\hline
\end{tabular}

With the statement No.5 agreement was also strong $(\mathrm{P}=0.0005)$ for English (Table 6).

TABLE 6

ANALYSIS OF STATEMENT 5

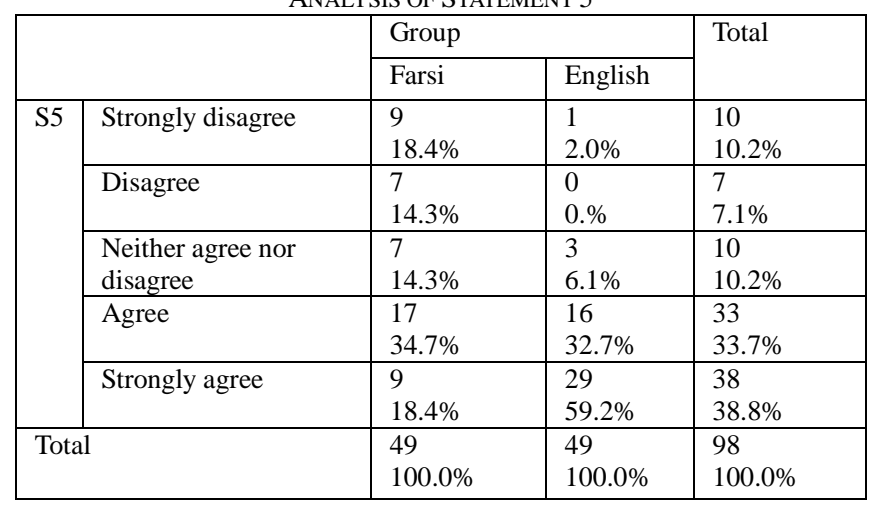




\begin{tabular}{|l|l|l|l|}
\hline Chi Squared Tests & Value & df & Asymp.Sig. (2 sided) \\
\hline Pearson Chi Square & 25.557 & 4 & .000 \\
Likelihood Ratio & 29.817 & 4 & .000 \\
Linear by Linear & 23.287 & 1 & .000 \\
Association & & & \\
N of Valid Cases & 98 & & \\
\hline
\end{tabular}

The ratio was $59.2 \%$ to $18.4 \%$. Differences between responses to statement No. 6 was highly significant $(\mathrm{P}=0.0005)$. $49.0 \%$ of the subjects believed that English gives them new insights into the world (Table 7).

TABLE 7

ANALYSIS OF STATEMENT 6

\begin{tabular}{|c|l|l|l|l|}
\hline \multicolumn{2}{|c}{} & Group & \multirow{2}{*}{ Total } \\
\cline { 3 - 4 } \multicolumn{2}{|c|}{} & Farsi & English & \\
\hline S6 & Strongly disagree & 8 & 1 & 9 \\
& & $16.7 \%$ & $2.0 \%$ & $9.3 \%$ \\
\cline { 2 - 4 } & Disagree & 5 & 1 & 6 \\
& & $10.4 \%$ & $2.0 \%$ & $6.2 \%$ \\
\cline { 2 - 5 } & Neither agree nor & 13 & 3 & 16 \\
& disagree & $27.1 \%$ & $6.1 \%$ & $16.5 \%$ \\
\cline { 2 - 4 } & Agree & 19 & 20 & 39 \\
& & $39.6 \%$ & $40.8 \%$ & $40.2 \%$ \\
\cline { 2 - 5 } & Strongly agree & 3 & 24 & 27 \\
& & $6.3 \%$ & $49.0 \%$ & $27.8 \%$ \\
\hline Total & 48 & 49 & 97 \\
& $100.0 \%$ & $100.0 \%$ & $100.0 \%$ \\
\hline
\end{tabular}

\begin{tabular}{|l|l|l|l|}
\hline Chi Squared Tests & Value & df & Asymp.Sig. (2 sided) \\
\hline Pearson Chi Square & 30.713 & 4 & .000 \\
Likelihood Ratio & 34.455 & 4 & .000 \\
Linear by Linear & 25.713 & 1 & .000 \\
Association & & & \\
N of Valid Cases & 97 & & \\
\hline
\end{tabular}

For statement No.7 the trend reversed, which was significant $(\mathrm{P}=0.117) .42 .6 \%$ of the subjects strongly agreed that Farsi has a great literature (Table 8).

TABLE 8

ANALYSIS OF STATEMENT 7

\begin{tabular}{|c|l|l|l|l|}
\hline \multicolumn{2}{|c}{} & \multicolumn{2}{|l}{ Group } & \multirow{2}{*}{ Total } \\
\cline { 3 - 4 } \multicolumn{2}{|c|}{} & Farsi & English & \\
\hline S7 & Strongly disagree & 4 & 5 & 9 \\
& & $8.5 \%$ & $10.2 \%$ & $9.4 \%$ \\
\cline { 2 - 4 } & Disagree & 4 & 4 & 8 \\
& & $8.5 \%$ & $8.2 \%$ & $8.3 \%$ \\
\cline { 2 - 5 } & Neither agree nor & 9 & 17 & 26 \\
& disagree & $19.1 \%$ & $34.7 \%$ & $27.1 \%$ \\
\cline { 2 - 4 } & Agree & 10 & 14 & 24 \\
& & $21.3 \%$ & $28.6 \%$ & $25.0 \%$ \\
\cline { 2 - 4 } & Strongly agree & 20 & 9 & 29 \\
& & $42.6 \%$ & $18.4 \%$ & $30.2 \%$ \\
\hline \multirow{2}{*}{ Total } & 47 & 49 & 96 \\
& & $100.0 \%$ & $100.0 \%$ & $100.0 \%$ \\
\hline
\end{tabular}

\begin{tabular}{|l|l|l|l|}
\hline Chi Squared Tests & Value & df & Asymp.Sig. (2 sided) \\
\hline Pearson Chi Square & 7.373 & 4 & .117 \\
Likelihood Ratio & 7.520 & 4 & .111 \\
Linear by Linear & 2.931 & 1 & .087 \\
Association & & & \\
N of Valid Cases & 96 & & \\
\hline
\end{tabular}

Regarding statement $8,34.7 \%$ of the subjects compared with $20.4 \%$ of them strongly believed that English pronunciation is beautiful. This was not significant $(\mathrm{P}=0.09)$. Only $2 \%$ rejected the idea that English has beautiful pronunciation (Table 9). 
TABLE 9

ANALYSIS OF STATEMENT 8

\begin{tabular}{|l|l|l|l|l|}
\hline \multicolumn{2}{|c}{} & \multicolumn{2}{|c|}{ Group } & \multirow{2}{*}{ Total } \\
\cline { 3 - 4 } \multicolumn{2}{|c|}{} & Farsi & English & \\
\hline S8 & Strongly disagree & 7 & 1 & 8 \\
& & $14.3 \%$ & $2.0 \%$ & $8.2 \%$ \\
\cline { 2 - 4 } & Disagree & 2 & 4 & 6 \\
& & $4.1 \%$ & $8.2 \%$ & $6.1 \%$ \\
\cline { 2 - 5 } & Neither agree nor & 11 & 7 & 18 \\
& disagree & $22.4 \%$ & $14.3 \%$ & $18.4 \%$ \\
\cline { 2 - 5 } & Agree & 19 & 20 & 39 \\
& & $38.8 \%$ & $40.8 \%$ & $39.8 \%$ \\
\cline { 2 - 4 } & Strongly agree & 10 & 17 & 27 \\
\cline { 3 - 4 } & $20.4 \%$ & $34.7 \%$ & $27.6 \%$ \\
\hline \multicolumn{2}{|l|}{ Total } & 49 & 49 & 98 \\
& $100.0 \%$ & $100.0 \%$ & $100.0 \%$ \\
\hline
\end{tabular}

\begin{tabular}{|l|l|l|l|}
\hline Chi Squared Tests & Value & df & Asymp.Sig. (2 sided) \\
\hline Pearson Chi Square & 7.896 & 4 & .095 \\
Likelihood Ratio & 8.499 & 4 & .075 \\
Linear by Linear & 4.632 & 1 & .031 \\
Association & & & \\
N of Valid Cases & 98 & & \\
\hline
\end{tabular}

Difference between responses to statement 9 is again large $(\mathrm{P}=0.0005) .38 .8 \%$ of the subjects compared to only $2.0 \%$ of them strongly believed that English is the language of science (Table 10).

TABLE 10

\begin{tabular}{|c|c|c|c|c|}
\hline & & \multicolumn{2}{|c|}{ Group } & \multirow[t]{2}{*}{ Total } \\
\hline & & Farsi & English & \\
\hline \multirow[t]{5}{*}{ S9 } & Strongly disagree & $\begin{array}{c}10 \\
20.4 \%\end{array}$ & $\begin{array}{c}1 \\
2.0 \%\end{array}$ & $\begin{array}{c}11 \\
11.2 \%\end{array}$ \\
\hline & Disagree & $\begin{array}{c}22 \\
44.9 \%\end{array}$ & $\begin{array}{c}6 \\
12.2 \%\end{array}$ & $\begin{array}{c}28 \\
28.6 \%\end{array}$ \\
\hline & $\begin{array}{c}\text { Neither agree nor } \\
\text { disagree }\end{array}$ & $\begin{array}{c}10 \\
20.4 \%\end{array}$ & $\begin{array}{c}5 \\
10.2 \%\end{array}$ & $\begin{array}{c}15 \\
15.3 \%\end{array}$ \\
\hline & Agree & $\begin{array}{c}6 \\
12.2 \%\end{array}$ & $\begin{array}{c}18 \\
36.7 \%\end{array}$ & $\begin{array}{c}24 \\
24.5 \%\end{array}$ \\
\hline & Strongly agree & $\begin{array}{c}1 \\
2.0 \%\end{array}$ & $\begin{array}{c}19 \\
38.8 \%\end{array}$ & $\begin{array}{c}20 \\
20.4 \%\end{array}$ \\
\hline & Total & $\begin{array}{c}49 \\
100.0 \%\end{array}$ & $\begin{array}{c}49 \\
100.0 \%\end{array}$ & $\begin{array}{c}98 \\
100.0 \%\end{array}$ \\
\hline
\end{tabular}

\begin{tabular}{|c|c|c|c|}
\hline Chi Squared Tests & Value & df & Asymp.Sig. (2 sided) \\
\hline Pearson Chi & 40.373 & 4 & .000 \\
Square & 46.030 & 4 & .000 \\
Likelihood Ratio & 38.249 & 1 & .000 \\
Linear by Linear & & & \\
Association & 98 & & \\
N of Valid Cases & & & \\
\hline
\end{tabular}

Finally, largest of all is the difference of opinion expressed about statement No. 10, where $71.4 \%$ compared to $4.1 \%$ strongly agreed that English gives them access to the Internet $(\mathrm{P}=0.0005)$ (Table 11).

TABLE 11

ANALYSIS OF STATEMENT 10

\begin{tabular}{|c|c|c|c|c|}
\hline & & \multicolumn{2}{|l|}{ Group } & \multirow[t]{2}{*}{ Total } \\
\hline & & Farsi & English & \\
\hline \multirow[t]{5}{*}{ S10 } & Strongly disagree & $\begin{array}{l}18 \\
36.7 \%\end{array}$ & $\begin{array}{l}1 \\
2.0 \%\end{array}$ & $\begin{array}{l}19 \\
19.4 \%\end{array}$ \\
\hline & Disagree & $\begin{array}{l}21 \\
42.9 \%\end{array}$ & $\begin{array}{l}0 \\
.0 \%\end{array}$ & $\begin{array}{l}21 \\
21.4 \%\end{array}$ \\
\hline & $\begin{array}{l}\text { Neither agree nor } \\
\text { disagree }\end{array}$ & $\begin{array}{l}5 \\
10.2 \% \\
\end{array}$ & $\begin{array}{l}0 \\
.0 \%\end{array}$ & $\begin{array}{l}5 \\
5.1 \% \\
\end{array}$ \\
\hline & Agree & $\begin{array}{l}3 \\
6.1 \%\end{array}$ & $\begin{array}{l}13 \\
26.5 \%\end{array}$ & $\begin{array}{l}16 \\
16.3 \%\end{array}$ \\
\hline & Strongly agree & $\begin{array}{l}2 \\
4.1 \%\end{array}$ & $\begin{array}{l}35 \\
71.4 \%\end{array}$ & $\begin{array}{l}37 \\
37.8 \%\end{array}$ \\
\hline \multicolumn{2}{|c|}{ Total } & $\begin{array}{l}49 \\
100.0 \%\end{array}$ & $\begin{array}{l}49 \\
100.0 \%\end{array}$ & $\begin{array}{l}98 \\
100.0 \%\end{array}$ \\
\hline
\end{tabular}




\begin{tabular}{|c|c|c|c|}
\hline Chi Squared Tests & Value & df & Asymp.Sig. (2 sided) \\
\hline Pearson Chi & 76.893 & 4 & .000 \\
Square & 97.018 & 4 & .000 \\
Likelihood Ratio & 67.621 & 1 & .000 \\
Linear by Linear & & & \\
Association & 98 & & \\
N of Valid Cases & & & \\
\hline
\end{tabular}

Group statistical analysis showed that all the means of responses to the statements about English, except for the means of responses to statements 7 and 8, were higher for English than Farsi (table 12).

TABLE 12

GROUP STATISTICAL ANALYSIS

\begin{tabular}{|c|c|c|c|c|c|}
\hline \multicolumn{2}{|c|}{ Group } & \multirow{2}{*}{$\begin{array}{l}\mathrm{N} \\
49\end{array}$} & \multirow{2}{*}{$\begin{array}{l}\text { Mean } \\
2.43 \\
3.94 \\
\end{array}$} & \multirow{2}{*}{$\begin{array}{l}\text { Std. Deviation } \\
1.099 \\
1.162 \\
\end{array}$} & \multirow{2}{*}{$\begin{array}{l}\text { P-value } \\
.000\end{array}$} \\
\hline S1 & $\begin{array}{l}\text { Farsi } \\
\text { English }\end{array}$ & & & & \\
\hline S2 & $\begin{array}{l}\text { Farsi } \\
\text { English }\end{array}$ & 49 & $\begin{array}{l}3.13 \\
3.83\end{array}$ & $\begin{array}{l}1.299 \\
1.342 \\
\end{array}$ & 0.10 \\
\hline S3 & $\begin{array}{l}\text { Farsi } \\
\text { English }\end{array}$ & 49 & $\begin{array}{l}3.73 \\
4.45\end{array}$ & $\begin{array}{l}1.319 \\
.867\end{array}$ & .020 \\
\hline S4 & $\begin{array}{l}\text { Farsi } \\
\text { English }\end{array}$ & 49 & $\begin{array}{l}2.98 \\
4.40\end{array}$ & $\begin{array}{l}1.266 \\
.844\end{array}$ & .000 \\
\hline S5 & $\begin{array}{l}\text { Farsi } \\
\text { English }\end{array}$ & 49 & $\begin{array}{l}3.20 \\
4.47\end{array}$ & $\begin{array}{l}1.399 \\
.793\end{array}$ & .000 \\
\hline S6 & $\begin{array}{l}\text { Farsi } \\
\text { English }\end{array}$ & 49 & $\begin{array}{l}3.08 \\
4.33 \\
\end{array}$ & $\begin{array}{l}1.200 \\
.851\end{array}$ & .000 \\
\hline S7 & $\begin{array}{l}\text { Farsi } \\
\text { English }\end{array}$ & 49 & $\begin{array}{l}3.81 \\
3.37 \\
\end{array}$ & $\begin{array}{l}1.313 \\
1.185 \\
\end{array}$ & .087 \\
\hline S8 & $\begin{array}{l}\text { Farsi } \\
\text { English }\end{array}$ & 49 & $\begin{array}{l}3.47 \\
3.98 \\
\end{array}$ & $\begin{array}{l}1.276 \\
1.010\end{array}$ & .310 \\
\hline S9 & $\begin{array}{l}\text { Farsi } \\
\text { English }\end{array}$ & 49 & $\begin{array}{l}2.31 \\
3.98 \\
\end{array}$ & $\begin{array}{l}1.004 \\
1.090 \\
\end{array}$ & .031 \\
\hline S10 & $\begin{array}{l}\text { Farsi } \\
\text { English }\end{array}$ & 49 & $\begin{array}{l}1.98 \\
4.65\end{array}$ & $\begin{array}{l}1.051 \\
.694\end{array}$ & .000 \\
\hline
\end{tabular}

This was confirmed by a 2 tailed $t$ test for equality of means (Table 13).

TABLE13

INDEPENDENT SAMPLES TEST

\begin{tabular}{|l|l|l|l|l|l|l|}
\hline \multicolumn{2}{|c|}{} & \multicolumn{2}{|l|}{ t-test for equality of means } \\
\cline { 3 - 7 } \multicolumn{2}{|c|}{} & $\mathrm{t}$ & $\mathrm{df}$ & $\begin{array}{l}\text { Sig. (2 } \\
\text { tailed) }\end{array}$ & $\begin{array}{l}\text { Mean } \\
\text { Difference }\end{array}$ & $\begin{array}{l}\text { Std. Error } \\
\text { Difference }\end{array}$ \\
\hline Mean & $\begin{array}{l}\text { Equal variances } \\
\text { assumed } \\
\text { Equal variances } \\
\text { not assumed }\end{array}$ & -8.202 & 96 & .000 & -1.1331 & .13816 \\
\hline
\end{tabular}

Overall, group comparison of the means was 4.1388 for English and 3.0057 for Farsi, which was significant $(\mathrm{P}=$ 0.0005) (Table 14).

TABLE 14

GROUP STATISTICS

\begin{tabular}{|l|l|l|l|l|l|}
\hline \multicolumn{2}{|l|}{ Group } & $\mathrm{N}$ & Mean & Std. Deviation & Std. Error Mean \\
\hline Mean & Farsi & 49 & 3.0057 & .80445 & .11492 \\
& English & 49 & 4.1388 & .53680 & .07669 \\
\hline
\end{tabular}

\section{DISCUSSION}

By all accounts, the results confirmed our hypothesis that attitude is the main cause of the problem under investigation. Gardner and Lambert (1972) suggest that both instrumental and integrative orientations affect language learning and motivation. The orientation is integrative when the student has a genuine interest in a specific cultural community and the intention of eventually being accepted into that group. Included are the appropriate behaviours that accompany acceptance into that language community. Instrumental orientation is characterized by the utility of language and the potential to gain economic advantages and/or increase social position through acquisition of that language.

Scholars of language motivation have suggested that integration orientation may be more important in successful 
second language acquisition than is instrumental orientation (Gardner, 1985; Gardner and Lambert, 1972). However, in this study it was indicated that this is not the case. Findings of this study showed that although Turks learn Farsi for integration purposes, and their learning English is mainly instrumental, they are more successful English language learners. Therefore to be a successful second language learner, one not only needs to have integrative orientation toward learning the language, but also needs to have a positive attitude toward the language itself.

Maximal vs. minimal distinction (Skutnab Kangas, 1984) has also been questioned by the findings of the study. Farsi as the most widespread and dominant language in Iran creates a maximal bilingualism situation for Turkish speaking people here. Therefore, it is assumed that they should be fluent in every aspect of Farsi. However, we showed that this is not the case. The most obvious deficiency is the pronunciation, where Iranian Turks do not let Turkish pronunciation go while speaking Farsi. The situation was compared with English learned by Turkish speaking students as an additive language. This may be considered as minimal bilingualism. English learning starts at only second year of junior secondary school and continues through the university years. Although exposure to English is very limited outside school, students speak it fluently with little trace of Turkish accent. Apparently true bilingualism takes root during childhood, and the child will have native command of the second language. In other words, as Bloomfield (1933) thought, the bilingual could be pictured as sum of two monoglots. The findings of the current research rejected the idea. After years of exposure to Farsi, the Iranian Turkish speaker did not turn to a new monoglot to be mixed with his first. Selinker (1971) may be right here that only five percent of second language speakers have absolute success in their second tongue.

Language proficiency has been a topic of discussion for many years. If language proficiency can be maximal (Haugen, 1953) or minimal (MacNamara, 1967), then, the former must dominate the latter. However, our study could not separate the border between maximal and minimal proficiency. Turkish learners of Farsi in our study did not display maximum proficiency in Farsi despite many years of exposure and learning. Their better command of English disturbed the balance between the opposite concepts of maximal/minimal proficiency. Here, MacNamara (1967) may be right that a bilingual is anyone who possesses a minimal competence in only one of the four language skills.

The findings of the current research showed that attitude plays an important role in SLA. According to the model of attitude developed by Rosenberg and Hovland (1960), the cognitive element of attitude concerns perception, concepts, and beliefs regarding the attitude object. For example a stated belief about the importance of a language and its value may contribute to a favourable attitude. The affective component of attitude includes feelings toward the object of the attitude, such as the language itself. Affect, according to Rosenberg and Hovland (1960), may include love or dislike of the language or anxiety over learning the language. Bringing answers to all statements in the questionnaires together supports the idea that perceptions, concepts, beliefs, love or dislike of a second language contributes to unbiased and free of anxiety learning of it. The findings of the research are also in line with Gardner's (1985) work in social psychology, where it is stated that attitude is only one component of motivation, and motivation is comprised of effort and desire to learn. Also, Baker's (1992) distinction of the various facets of attitude in relation to language supports the thought that positive attitudes toward a particular language paves the way for better learning.

\section{CONCLUSION}

Bilingualism classified as minimal and maximal was questioned by observing the presence of Turkish accent in the Iranian Turkish speaking people's Farsi. This was contrasted with the absence of Turkish accent in these people's English. The findings of the research proved that positive attitude toward a second language is an important determinant in the learning outcome. Although Farsi is a second language for Turks in Iran and described as maximal in bilingualism terms is not a psychologically dominant second language. Contrasted with it, English considered as minimal or incipient for most Iranians, particularly for Turkish speaking Iranians, seems to be psychologically dominant. Such dominance could be a result of positive attitude towards the latter.

\section{APPENDIX A}

For each of the statements below, please indicate the extent of your agreement or disagreement by placing a tick in the appropriate column. 


\begin{tabular}{|c|c|c|c|c|c|}
\hline & 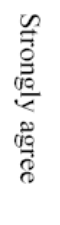 & $\underset{\overrightarrow{00}}{\overrightarrow{0}}$ & 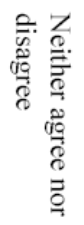 & 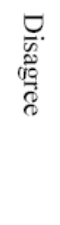 & 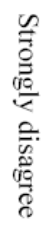 \\
\hline \multicolumn{6}{|l|}{ 1. I'd Like to speak Farsi all the time. } \\
\hline \multicolumn{6}{|l|}{ 2. Learning Farsi is a privilege. } \\
\hline \multicolumn{6}{|c|}{ 3. Farsi is a very attractive language. } \\
\hline \multicolumn{6}{|c|}{ 4. Knowing Farsi will help you get a better job. } \\
\hline \multicolumn{6}{|c|}{ 5. Learning Farsi is a great pleasure. } \\
\hline \multicolumn{6}{|c|}{ 6. Farsi gives me new insights into the world. } \\
\hline \multicolumn{6}{|l|}{ 7. Farsi has a great literature. } \\
\hline \multicolumn{6}{|l|}{ 8. Farsi pronunciation is beautiful. } \\
\hline \multicolumn{6}{|l|}{ 9. Farsi is the language of science. } \\
\hline 10. Farsi gives me access to the Internet. & & & & & \\
\hline
\end{tabular}

\section{APPENDIX B}

For each of the statements below, please indicate the extent of your agreement or disagreement by placing a tick in the appropriate column.

\begin{tabular}{l}
\cline { 2 - 6 }$l \mid$ \\
\cline { 3 - 6 }
\end{tabular}

\section{REFERENCES}

[1] Baetens Beardsmore, H. (1982). Bilingualism: Basic principles. Cleveddon: Multilingual Matters Ltd.

[2] Baker, C. (1992). Attitudes and Language. Clevedon: Multilingual Matters Ltd.

[3] Baker, C. \& S. P. Jones. (1998). Encyclopedia of Bilingualism and Bilingual Education. Clevedon: Multilingual Matters Ltd.

[4] Birdsong, D. (1992). Ultimate Attainment in Second Language Attainment. Language, 68, 706-753.

[5] Bley Vorman, R. (1989). The logical problem of second language learning. In S. Gass \& J. Schanchter (eds.), Linguistic Perspectives on Second Language Acquisition. Cambridge, UK: Cambridge University Press.

[6] Bloomfield, L. (1933). Language. London: Allen and Unwin.

[7] Cook, V. (1993). Linguistics and Second Language Acquisition. Basingstoke: Macmillan.

[8] Fowler, F. J. (1993). Survey research methods. Newbury Park, CA: Sage Publications.

[9] Gardner, R. C. \& W. E. Lambert (1972). Attitudes and motivation in second language learning. Rowley, MA: Newbury House Publications.

[10] Gardner, R. C. (1985). Social psychology and second language learning: The role of attitudes and motivation. Bungay: Suffolk Edward Arnold.

[11] Hamers, J. \& M. Blanc. (2000). Bilinguality and Bilingualism. Cambridge, UK: Cambridge University Press.

[12] Hasselmo, N. (1970). Code switching and modes of speaking. In G. Gilbert (ed.), Texas studies in bilingualism. Berlin: Walter de Gruyter, 179-210.

[13] Haugen, E. (1953). The Norwegian language in America. Pennsylvania: University of Pennsylvania Press.

[14] Henerson, M. E., L. L. Morris \& C. T. Fitz Gibbon. (1987). How to Measure Attitudes. Thousand Oaks, CA: Sage Publication.

[15] Hill, L. A. (1979). Elementary. Stories for Reproduction: Series 2. Oxford: Oxford University Press.

[16] Mackey, W. F. (1976). Bilingualism et contact des language. Paris: Klicksiek.

[17] MacNamara, J. (1967). The bilingual's linguistic performance: A psychological overview. Journal of Social Issues, $23,59-77$. 
[18] Rosenberg, M. J. \& C. Hovland. (1960). Cognitive, affective, and behavioral components of attitudes. In C. Hovland \& M. J. Rosenberg (eds.), Attitude organization and change. New Haven: Yale University Press.

[19] Selinker, L. B. (1971). Interlanguage. IRAL 10, 3.

[20] Shaw, M. \& J. Wright. (1967). Scales for the measurement of attitudes. New York: MCGraw Hill.

[21] Skutnabb Kangas, T. (1984). Biligualism or Not: The Education of Minorities. Clevedon: Multilingual Matters LTD.

[22] Toribio, A. J. (2001). On the Emergence of Bilingual. Code switching competence. Bilingualism: Language and cognition 4.3, 203-232.

[23] Weinreich, U. (1966). Languages in Contact: Findings and Problems. The Hague: Mouton.

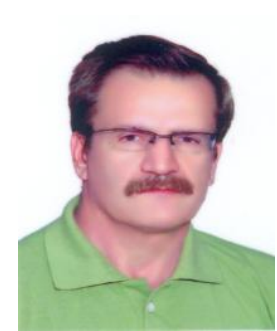

Ataollah Maleki is currently Associate Professor of TEFL at Zanjan Medical University, IRAN. His main interest of research is communication strategies, EFL teaching, teaching and testing, ESP, discourse analysis, and phonetics. He has been engaged in teaching English and applied linguistics for more than twenty years. He holds a Ph. D degree in TEFL, an MA in TEFL, and a postgraduate diploma in applied linguistics and phonetics. He has published a number of books and articles in his areas of interest in academic journals. 